DOI: 10.46340/eppd.2020.7.4.29

\author{
Andrii Pastukh \\ ORCID ID: https://orcid.org/0000-0002-5890-4876 \\ Sokal department of the Chervonohrad local prosecutor's office \\ of the Lviv region, Ukraine
}

\title{
PROBLEM ISSUES ARISING DURING THE COURT HEARING OF RECONCILIATION AND PLEA AGREEMENTS RECEIVED BY THE COURT WITH INDICTMENTS
}

\author{
Андрій Пастух \\ Сокальський відділ Червоноградської місцевої прокуратури Львівської області, \\ Україна
}

\section{ПРОБЛЕМНІ ПИТАННЯ, ЯКІ ВИНИКАЮТЬ ПІД ЧАС РОЗГЛЯДУ СУДОМ УГОД ПРО ПРИМИРЕННЯ ТА ПРО ВИЗНАННЯ ВИНУВАТОСТІ, ЯКІ НАДЙШЛИ ДО СУДУ $З$ ОБВИНУВАЛЬНИМИ АКТАМИ}

The article is devoted to the identification of problematic issues that arise in practice during the preparatory court hearing on the court's consideration of reconciliation or guilty plea agreements received by the court with indictments.

In particular, during the research process we consider the most problematic issues and gaps in the legislation that daily participants face during the court hearing of agreements submitted to the court at the same time as the indictment, at the preparatory court stage, as well as ways to solve them. Thus, among other things, attention was drawn to the ambiguity of the positions of the courts in resolving the issue of refusal to approve agreements, the ambiguity of the legislator, the possibility of the court to get acquainted with the materials of criminal proceedings, the issue of approving agreements, and also attention is drawn to the problem, faced in practice, in relation to the legally established norm of the prohibition to apply twice with an agreement in one criminal proceeding. Keywords: plea agreement, reconciliation agreement, bench ruling, preparatory proceeding, approval of the agreement, refusal to approve the agreement.

\section{Постановка проблеми.}

Одним із прогресивних положень Кримінального процесуального кодексу України (КПК), на думку вчених та практиків, так і міжнародних експертів, є запровадження в Україні відновного правосуддя, найбільш відомим інструментом якого $є$ медіація, суть якої в контексті кримінального судочинства полягає у примиренні, досягненні консенсусу між сторонами та врегулюванні соціального конфлікту.

Передбачалося, що із появою глави 35 «Кримінальне провадження на підставі угод» у кримінальному процесуальному законодавстві значно спроститься процедура розгляду певної категорії кримінальних справ ${ }^{1}$.

Однак, у зв'язку із неоднозначними положеннями чинного КПК України на практиці часто трапляються різні ситуації, що призводить до постановки судом спірних рішень.

У зв'язку із наведеним, суду при вирішенні на стадії підготовчого провадження, питання щодо затвердження угод про примирення та визнання винуватості необхідне чітке законодавче

\footnotetext{
1 Узагальнення ВССУ судової практики здійснення кримінального провадження на підставі угод від 22.01.2014. Закон і Бізнес. <https://zib.com.ua/ua/print/92557-uzagalnennya_vssu_sudovoi_praktiki_ zdiysnennya_kriminalnogo.htm $>$.
} 
врегулювання, алгоритм дій при тій чи іншій ситуації, що позбавило б можливості недобросовісних учасників спекулювати на прогалинах законодавства.

\section{Стан дослідження.}

Питання затвердження та відмова в затвердженні угод про примирення та визнання винуватості висвітлені в наукових дослідженнях наступних вчених: С.В. Андрусенко, О.В. Бабаєва, І.В. Гловюк, В.О. Гринюк, М.С. Квятковський, О.О. Леляк, О.І. Литвинчук, К.І. Пащенко, М.Г. Твердохліб, M.I. Хавронюк, та інших. Однак, в своїх працях науковці висвітлювали здебільшого практичні аспекти при розгляді судом угод на стадії підготовчого провадження, а практичні проблеми, з якими щодня стикаються учасники провадження повною мірою не знайшли свого відображення.

Тому метою статті $\epsilon$ встановлення законодавчих прогалин під час розгляду судом, на стадії підготовчого провадження, угод про примирення та визнання винуватості, які надійшли до суду одночасно з обвинувальним актом, а також шляхи їх вирішення.

\section{Виклад основного матеріалу.}

Відповідно до ст. 468 КПК у кримінальному провадженні може бути укладено два види угод, один з яких - угода про примирення між потерпілим та підозрюваним чи обвинуваченим, другий угода між прокурором та підозрюваним чи обвинуваченим про визнання винуватості.

Якщо угоди (незалежно від іiі виду) досягнуто під час досудового розслідування, після виконання процесуальних дій, передбачених статей 290, 291 КПК України, складений слідчим та затверджений прокурором обвинувальний акт разом із підписаною сторонами угодою невідкладно надсилається до суду. Відкласти направлення цих документів до суду вправі, відповідно до ч. 1 ст. 474 КПК України, лише прокурор за наявності визначених процесуальним законом підстав, зокрема у зв'язку із необхідністю: 1) отримання висновку експерта; 2) завершення проведення інших слідчих дій, необхідних для збирання і фіксації доказів, які можуть бути втрачені зі спливом часу, або які неможливо буде провести пізніше без істотної шкоди для їх результату у разі відмови суду в затвердженні угоди.

Згідно вимог ст. 314 КПК України у підготовчому судовому засіданні суд має право прийняти рішення про затвердження угоди або відмовити в затвердженні угоди та повернути кримінальне провадження прокурору для продовження досудового розслідування в порядку, передбаченому статтями 468-475 цього Кодексу.

Аналізуючи чинні норми кримінального процесуального кодексу, а також дослідивши Постанову пленуму Вищого спеціалізованого суду України з розгляду цивільних та кримінальних справ №13 від 11.12.2015 «Про практику здійснення судами кримінального провадження на підставі угод» слід дійти висновку, що за наслідками розгляду угоди, зокрема нас цікавить під час підготовчого судового провадження, суд перевіривши відповідність угоди вимогам кримінального процесуального закону і закону про кримінальну відповідальність, врахувавши доводи сторін кримінального провадження та інших учасників судового провадження, має прийняти одне із таких рішень:

а) затвердити угоду про примирення, або

б) відмовити у затвердженні угоди в разі встановлення підстав, передбачених ч. 7 ст. 474 КПК України, та: повернути кримінальне провадження прокурору, якщо угоди досягнуто під час досудового розслідування, для його продовження у порядку, передбаченому розділом III КПК України; або продовжити судовий розгляд у загальному порядку, якщо угоду було укладено під час його здійснення; або призначити судовий розгляд для проведення судового провадження в загальному порядку, якщо до суду надійшов обвинувальний акт, а угоду було укладено під час підготовчого провадження, а також у випадку подання прокурором відповідного клопотання, пов'язаного з відсутністю необхідності продовження досудового розслідування внаслідок його фактичного закінчення. При цьому, зокрема в останньому випадку, слід неухильно дотримуватися вимог закону щодо відкриття сторонами кримінального провадження одне одній додаткових матеріалів, отриманих до або під час судового розгляду ${ }^{1}$.

Зупинимось на укладенні угоди про примирення між потерпілим та підозрюваним на стадії досудового розслідування, після чого, прокурор, як спостерігач укладення вказаного виду угоди, ніяким чином не впливаючи на цей процес після затвердження угоди зобов'язаний таку із обвинувальним актом негайно скерувати в суд, лише у виключних випадках, які наведено вище, він вправі одразу до суду не скеровувати таку угоду.

\footnotetext{
${ }^{1}$ Постанова про практику здійснення судами кримінального провадження на підставі угод 2015 (Пленум Вищого спеціалізованого суду України з розгляду цивільних та кримінальних справ).
} 
Виходячи 3 практичного досвіду, за результатами підготовчого судового засідання суди $\epsilon$ не однозначними щодо вирішення питання про повернення обвинувального акту, якщо судом 3 тих чи інших підстав відмовлено в затвердженні угоди про примирення.

Так, в одних випадках суд відмовляє в затвердженні угоди про примирення та повертає обвинувальний акт прокурору, хоча доцільності в цьому немає, оскільки проведено всі необхідні слідчі (розшукові) дії, при цьому суд посилається на п.1 ч.3 ст.314 КПК України, де визначено, що у підготовчому судовому засіданні суд має право затвердити угоду або відмовити в затвердженні угоди та повернути кримінальне провадження прокурору для продовження досудового розслідування в порядку, передбаченому статтями 468-475 цього Кодексу (рішення Червоноградського міського суду Львівської області № 459/843/17) ${ }^{1}$.

В інших випадках, коли суд відмовляє в затвердженні угоди про примирення то він призначає судовий розгляд в загальному порядку (рішення Червоноградського міського суду Львівської області від №459/1058/17)².

Аналогічна ситуація складається при вирішенні питання щодо затвердження угод про визнання винуватості, судді $є$ також не однозначними у вирішенні питань про відмову в затвердженні угоди про визнання винуватості і поверненні обвинувального акту прокурору.

До прикладу в однакових випадках суди приймають різні за змістом рішення, в одному випадку коли суд відмовляє в затвердженні угоди про визнання винуватості призначається судовий розгляд (рішення Червоноградського міського суду №459/1934/16-к)3, а в іншому навпаки (рішення Кам’янкоБузького районного суду Львівської області №446/2168/16-к) ${ }^{4}$.

Аналогічну ситуацію, щодо прийняття судами різних рішень під час вирішення питання про затвердження угоди під час підготовчого провадження, яка надійшла до суду разом з обвинувальним актом висвітлює і Пащенко К.І. ${ }^{5}$

У зв'язку, із неоднозначною практикою судів при розгляді таких обвинувальних актів з угодами про визнання винуватості, а також з угодами про примирення, призводить до того, що кількість угод, які скеровуються прокуратурою до суду, зменшується, а це насамперед пов'язано з тим, що які б реформи не відбувались, але все таки повернення обвинувального акту в органах прокуратури все ще рахується недоліком в роботі.

3 наведеного вбачається, що в чинний КПК України необхідні негайні зміни, які по своїй суті усунули б вказані прогалини та позбавили б зловживань, якими інколи користуються учасники процесу, з метою затягування судового розгляду.

Вказані факти породженні тим, що в чинному КПК України чітко не прописано, які дії має вчинити суд у випадку відмови в затвердженні угоди про примирення та обвинувальний акт відповідає вимогам вказаного закону.

Такої ж думки притримується Хавронюк М.І., який зазначає, що частина 7 ст. 474 КПК містить перелік підстав, за яких суд не може, а зобов'язаний відмовити в затвердженні угоди. Проте деякі 3 них $є$ надто дискреційними. Наприклад, ніхто не здатен абсолютно точно визначити, чи відповідають умови угоди інтересам суспільства, чи порушують вони інтереси сторін, а тим більше інших осіб

У цій же нормі вказано, що за наявності однієї з перелічених підстав досудове розслідування або судове провадження продовжуються у загальному порядку. Але яке рішення повинен прийняти суд для того, щоб повернути справу в русло загального порядку, на відміну від ч. 3 ст. 476 КПК, у ст. 474 цього Кодексу не вказано ${ }^{6}$.

\footnotetext{
${ }^{1}$ Ухвала у провадженні № 1-кn/459/150/2017 2017 (Червоноградський міський суд Львівської області). $<$ http://www.reyestr.court.gov.ua/Review/66097457>.

${ }^{2}$ Ухвала у провадженні № 1-кn/459/175/2017 2017 (Червоноградський міський суд Львівської області).

$<$ http://www.reyestr.court.gov.ua/Review/66453126>.

3 Ухвала Червоноградського міського суду Львівської області 2016 за № 459/1934/16-к.

$<$ http://www.reyestr.court.gov.ua/Review/59237276>.

${ }^{4}$ Ухвала Кам'янко-Бузького районного суду Львівської області від 08.02.2017 за №446/2 168/16-к.

$<$ http://www.reyestr.court.gov.ua/Review/64603727>.

5 Пащенко, К.І. (2018). Проблемні питання під час здійснення процесуального керівництва в кримінальних провадженнях на підставі угод про визнання винуватості». Науковий вісник Ужгородського національного університету, Серія Право, 52, 2.

${ }_{6}^{6}$ Хавронюк, М.І. (2017). «Правопрокурорря», або Деякі проблеми угоди про визнання винуватості. $<$ http://pgp-journal.kiev.ua/archive/2017/4/34.pdf>.
} 
Такі випадки нажаль $є$ непоодинокими, що призводить, в загальному до затягування розгляду кримінального провадження, а також до порушення розумних строків.

На мою думку з врахуванням норм КПК України та судової практики слід внести зміни до чинного кримінального процесуального законодавства України, і в тому випадку коли суд буде відмовляти в затвердженні угоди про примирення чи визнання винуватості, відсутні інші підстави для повернення обвинувального акту, а також у разі відсутності клопотань сторін про повернення обвинувального акту для проведення подальшого досудового розслідування суд повинен призначати провадження до судового розгляду в загальному порядку.

Крім цього, наступним проблемним питанням 3 яким стикаються учасники процесу на практиці $\epsilon$ перевірка угоди вимогам КПК України, на підставі зібраних під час досудового розслідування матеріалів кримінального провадження.

Так, у відповідності до ч.7 ст. 474 КПК України суд перевіряє угоду на відповідність вимогам цього Кодексу та/або закону ${ }^{1}$.

Згідно чинного КПК України фактично до суду скеровується обвинувальний акт, реєстр матеріалів досудового розслідування, розписка підозрюваного, та за наявності його захисника про отримання вказаних документів, а також, у нашому випадку угода, інші документи суду не надаються, і в принципі надання інших документів не передбачено.

Виникає питання яким чином суд в повній мірі може дослідити всі документи, які необхідні для прийняття законного рішення у справі. На практиці, яка доречі не однозначна суди витребовують у сторони обвинувачення матеріали кримінального провадження, хоча законність таких дій суду $є$ спірна, оскільки відповідно до ст. 291 КПК України, надання суду інших документів, до початку судового розгляду забороняється, а підготовче провадження та судовий розгляд, хоч і містяться в розділі 4 КПК України - «Судове провадження упершій інстанції», однак у різних главах, відповідно 27 - «Підготовче провадження» і 28 - «Судовий розгляд», а тому у підготовче засідання, згідно чинного КПК України сторона обвинувачення не праві надавати будь - які інші документи, що загалом по своїй суті є абсурдом.

Напрочуд Квятковський М.С. зазначає, що суду при надходженні одночасно з обвинувальним актом угоди, необхідно витребовувати в сторони обвинувачення матеріали кримінального провадження для можливості суду прийняти законне рішення усправі, узв'язку із тим, що затвердженням угоди справа вирішується по суті у підготовчому засіданні, яке фактично є і «судовим» в тому аспекті, як це буквально розуміють представники обвинувачення, оскільки необхідно дослідити і інші матеріали кримінального провадження, необхідні для прийняття рішення по суті, а не лише ті матеріали, що зазначені у ч.4 ст.291 КПК України, судам слід приймати рішення про відкладення підготовчого засідання для можливості надати стороною обвинувачення матеріалів, і у випадку відмови прокурора надавати суду матеріали, відповідно реагувати на адресу вищестоящого прокурора, а у випадку повторного ненадання матеріалів по угодах про визнання винуватості, відмовляти узатвердженні таких угод під час підготовчого судового засідання, та повертати кримінальне провадження для продовження досудового розслідування, оскільки суд був позбавлений можливості перевірити угоду на предмет іï відповідності вимогам КК України і КПК України. ${ }^{2}$

Гловюк І.В. та Андрусенко С.В. також схиляються до думки, що суду необхідно витребовувати документи ( матеріали провадження) в сторони обвинувачення, для можливості перевірки угоди вимогам КПК України, а також зазначають, що завдання прокурора із доведення відповідності/невідповідності угоди вимогам закону полегшується наявністю у суду матеріалів кримінального провадження ${ }^{3}$.

\footnotetext{
${ }^{1}$ Кримінальний прочесуальний кодекс України 2012 (Верховна Рада України). Офіційний сайт Верховної Ради України. <http://www.zakon2.rada.gov.ua/laws/show/4651-17>.

${ }^{2}$ Квятковський, М.С. (2013). Проблемні питання кримінального провадження на підставі угод про визнання винуватості та про примирення у кримінальному провадженні. Слово національної школи суддів України, 4(5). $<$ http://www.irbisnbuv.gov.ua/cgibin/irbis_nbuv/cgiirbis_64.exe?I21DBN=LINK\&P21DBN=UJRN\&Z21ID= \&S21REF= $10 \& S 21 C N R=20 \& S 21 \mathrm{STN}=1 \& S 21 \mathrm{FMT}=\mathrm{ASP}$ meta\&C21COM=S\&2_S21P03=FILA=\&2_S21STR=cln_2013_4_27>. ${ }^{3}$ Гловюк, I.В., Андрусенко, С.В. (2015). Проблемні аспекти участі прокурора у судовому провадженні на підставі угод. Вісник кримінального судочинства, 2. <http://www.irbis-nbuv.gov.ua/cgibin/irbis_nbuv/ cgiirbis_64.exe?I21DBN=LINK\&P21DBN=UJRN\&Z21ID =\&S21REF=10\&S21CNR=20\&S21STN=1\&S21FMT $=$ ASP_meta\&C21COM=S\&2_S21P03 $=$ FILA=\&2_S21STR=vkc_2015_2_3>.
} 
У відповідності до п.4 Інформаційного листа Вищого спеціалізованого суду України з розгляду цивільних і кримінальних справ від 15.11.2012 «Про деякі питання здійснення кримінального провадження на підставі угод» одночасно із прийняттям рішення суд, що здійснюватиме судове провадження, для реалізації покладених на нього обов'язків щодо з'ясування добровільності укладення угоди та перевірки її на відповідність вимогам КПК та/або кримінального закону (частини 6, 7 ст. 474 КПК), враховуючи, що невиконання вимог, встановлених частинами 5 - 7 ст. 474 КПК, $є$ підставою для апеляційного та касаційного оскарження (частини 3, 4 статей 394, 424 КПК), а в разі підтвердження таких порушень скасування судового рішення, має витребувати документи, подані сторонами під час досудового розслідування ${ }^{1}$.

У зв’язку із наведеним, було б слушним внести зміни в статтю 291 КПК України, в якій зазначити, що одночасно із скеруванням до суду обвинувального акту прокурор передає всі забрані під час досудового розслідування матеріали кримінального провадження.

Можливо вказана позиція в когось і викличе непорозуміння з мотивацією того, що це порушує процес змагальності.

Напрочуд для обгрунтування вказаної позиції можу зазначити, що сам факт передачі матеріалів ще нічого не свідчить, це стосується як підготовчого засідання при розгляді угод так і в загальному порядку, оскільки в подальшому у відповідності до вимог КПК України суд встановлює порядок дослідження доказів, під час чого прокурор може зазначати суду дослідити лише необхідні докази.

Крім цього, передача матеріалів провадження надасть змогу стороні захисту, у відповідності до вимог ст. 317 КПК України знайомитись із усією справою після ії надходження до суду, та в свою чергу позбавить прокурора, в ході судового розгляду подавати ті чи інші документи, які не знаходяться у поданій суду справі, оскільки такі вже будуть в суду, а матиме право лише зазначити які необхідно суду дослідити докази.

Наступним наріжним каменем в практичній діяльності щодо розгляду судом угод під час підготовчого судового засідання є вимоги ч. 8 ст. 474 КПК України щодо недопущення повторного звернення з угодою в одному кримінальному провадженні.

В науковій літературі вказана норма закону викликає багато дискусії, яка загалом зводиться до одного спільного рішення щодо необхідності зміни такої норми та надання можливості повторно звертатись з угодою в одному кримінальному провадженні. Зокрема таку позицію підтримують Лялек О.О., яка пропонує повторно звертатися з угодою про визнання винуватості в одному кримінальному провадженні у разі усунення або зміни обставин, визначених п. п. 1, 3 та п. 5 ч. 7 ст. 474 КПК України. які стали підставою для відмови в її затвердженні судом. Якщо ж повторно направлена угода все одно не відповідатиме вимогам законодавства, суду слід відмовляти в іiі затвердженні, а досудове розслідування або судове провадження продовжувати в загальному порядку².

Литвинчук О.І. притримується вказаної думки та зазначає, що зміст ч. 8 ст. 474 КПК України не відповідає загальній меті диференціації процесуальної форми ${ }^{3}$.

Свою позицію з даного приводу висловлено у п. 12 постанови Пленуму ВССУ «Про практику здійснення судами кримінального провадження на підставі угод» від 11.12.2015 №13, де зазначено, що якщо в угоді наявні недоліки, які за своїм змістом не $\epsilon$ суттєвими, зокрема угода вміщує суперечності, неточності, що обумовлено, переважно, правовою необізнаністю сторін, з огляду на заборону, передбачену ч. 8 ст. 474 КПК, щодо повторного звернення з угодою в одному кримінальному провадженні правильним видається надання судом можливості сторонам уточнення укладеної угоди, внесення відповідних змін до ії змісту. При цьому такі зміни мають бути погоджені між сторонами, відображені в журналі судового засідання, технічному записі та судовому рішенні ${ }^{4}$.

Позицію ВССУ також підтримує Твердохліб М.Г., який крім іншого, вбачає за доцільне законодавчо передбачити процедуру надання судом часу сторонам для усунення наявних в угоді недоліків, зокрема у разі недотримання ними вимог ст. ст. 471, 472 КК України щодо змісту угоди,

\footnotetext{
${ }^{1}$ Інформаційний лист Про деякі питання здійснення кримінального провадження на підставі угод 2012 (Вищий спеціалізований суд України з розгляду цивільних і кримінальних справ).

$<$ https://zakon.rada.gov.ua/laws/show/v1679740-12\#Text>.

2 Лялек, О.О. (2015). Угода про визнання винуватості у кримінальному процесі України. Київ.

3 Литвинчук O.I. (2018). Особливості кримінального провадження на підставі угод. Вісник ЛДУВС

ім. Е.О. Дідоренка, вип. 2 (82).

${ }^{4}$ Постанова про практику здійснення судами кримінального провадження на підставі угод 2015 (Пленум ВССУ). Офіціийний сайт Верховної Ради Украӥни. <https://zakon.rada.gov.ua/laws/show/v0013740-15\#Text>.
} 
допущення неправильної правової кваліфікації кримінального правопорушення, яка не виключає можливості укладення угоди у конкретному провадженні або ж недотримання вимог КК України при визначенні винному міри покарання (кримінальної відповідальності) ${ }^{1}$.

Позиція вказаних науковців, а також багатьох інших заслуговує на увагу та 3 такою слід погодитись, оскільки повторне звернення з угодою в одному кримінальному провадженні, або надання часу на усунення недоліків зекономить в свою чергу процесуальний час та буде сприяти дотримання досудового та судового розгляду в розумні строки.

\section{Висновки.}

За результатами проведеного дослідження, визначено ряд проблемних питань КПК України та зазначено шляхи їх вирішення.

У зв’язку із чим, пропонується внести наступні зміни до чинного КПК України, що у разі випадку відмови суду в затвердженні угоди про примирення та визнання винуватості, при відсутності інших підстав для повернення обвинувального акту, а також у разі відсутності клопотань сторін про повернення обвинувального акту для проведення подальшого досудового розслідування суд повинен призначати провадження до судового розгляду в загальному порядку.

Наступним моментом, який би, на нашу думку, сприяв дотриманню законності під час кримінального провадження є необхідність внесення змін в статтю 291 КПК України, в якій зазначити, що одночасно із скеруванням до суду обвинувального акту прокурор передає суду всі забрані під час досудового розслідування матеріали кримінального провадження.

Ще одними позитивними змінами було б внесення змін в КПК України щодо повторного звернення з угодою в одному кримінальному провадженні, або надання часу на усунення недоліків.

\section{References:}

1. Hloviuk, I.V., Andrusenko, S.V. (2015). Problemni aspekty uchasti prokurora u sudovomu provadzhenni na pidstavi uhod [Problematic aspects of the prosecutors participation in court proceedings on the basis of agreements]. Visnyk kryminalnoho sudochynstva [Bulletin of criminal proceedings], no. 2. <http://www.irbis-nbuv.gov.ua/ cgibin/irbis_nbuv/cgiirbis_64.exe?I21DBN=LINK\&P21DBN=UJRN\&Z21ID=\&S21REF=10\&S21CNR=20\&S21 $\mathrm{STN}=1 \& \mathrm{~S} 21 \mathrm{FMT}=\mathrm{ASP} \_$meta\&C21COM=S\&2_S21P03=FILA=\&2_S21STR=vkc_2015_2_3>. [in Ukrainian].

2. Informatsiinyi lyst Pro deiaki pytannia zdiisnennia kryminalnoho provadzhennia na pidstavi uhod 2012 [Information letter On some issues of criminal proceedings on the basis of agreements in 2012] (Vyshchyi spetsializovanyi sud Ukrainy z rozghliadu tsyvilnykh i kryminalnykh sprav) [(Supreme Specialized Court of Ukraine for Civil and Criminal Cases)]. <https://zakon.rada.gov.ua/laws/show/v1679740-12\#Text>. [in Ukrainian].

3. Kviatkovskyi, M.S. (2013). Problemni pytannia kryminalnoho provadzhennia na pidstavi uhod pro vyznannia vynuvatosti ta pro prymyrennia u kryminalnomu provadzhenni [Problematic issues of criminal proceedings on the basis of plea agreements and conciliation in criminal proceedings]. [Word of the National School of Judges of Ukraine ], no. 4(5). <http://www.irbisnbuv.gov.ua/cgibin/irbis_nbuv/cgiirbis_64.exe?I21DBN=LINK\&P21DBN= $\mathrm{UJRN} \& Z 21 \mathrm{ID}=\& \mathrm{~S} 21 \mathrm{REF}=10 \& \mathrm{~S} 21 \mathrm{CNR}=20 \& \mathrm{~S} 21 \mathrm{STN}=1 \& \mathrm{~S} 21 \mathrm{FMT}=\mathrm{ASP} \_$meta\&C $21 \mathrm{COM}=\mathrm{S} \& 2 \_\mathrm{S} 21 \mathrm{P} 03=\mathrm{FIL}$ $\mathrm{A}=\& 2 \_\mathrm{S} 21 \mathrm{STR}=\mathrm{cln} \_2013 \_4 \_27>$. [in Ukrainian].

4. Kryminalnyi protsesualnyi kodeks Ukrainy 2012 [Criminal Procedure Code of Ukraine 2012] (Verkhovna Rada Ukrainy) [(Verkhovna Rada of Ukraine)]. Ofitsiinyi sait Verkhovnoi Rady Ukrainy [Official site of the Verkhovna Rada of Ukraine]. <http://www.zakon2.rada.gov.ua/laws/show/4651-17>. [in Ukrainian].

5. Lytvynchuk, O.I. (2018). Osoblyvosti kryminalnoho provadzhennia na pidstavi uhod [Features of criminal proceedings on the basis of agreements]. Visnyk LDUVS im. E.O. Didorenka [Bulletin of LSUVS named after E.O. Didorenko], iss. 2 (82). [in Ukrainian].

6. Lialek, O.O. (2015). Uhoda pro vyznannia vynuvatosti u kryminalnomu protsesi Ukrainy [Plea agreement in the criminal process of Ukraine]. Kyiv. [in Ukrainian].

7. Pashchenko, K.I. (2018). Problemni pytannia pid chas zdiisnennia protsesualnoho kerivnytstva v kryminalnykh provadzhenniakh na pidstavi uhod pro vyznannia vynuvatosti» [Problematic issues during the implementation of procedural guidance in criminal proceedings on the basis of plea agreements]. Naukovyi visnyk Uzhhorodskoho natsionalnoho universytetu, Seriia Pravo [Scientific Bulletin of Uzhhorod National University, Law Series], vol. 52, 2. [in Ukrainian].

8. Postanova pro praktyku zdiisnennia sudamy kryminalnoho provadzhennia na pidstavi uhod 2015 (Plenum Vyshchoho spetsializovanoho sudu Ukrainy z rozghliadu tsyvilnykh ta kryminalnykh sprav). [in Ukrainian].

\footnotetext{
${ }^{1}$ Твердохліб, М.Г. (2016). Проблеми законодавчого вдосконалення кримінального провадження на підставі угод. Порівняльно аналітичне право, 1.
} 
9. Postanova pro praktyku zdiisnennia sudamy kryminalnoho provadzhennia na pidstavi uhod 2015 [Resolution on the practice of criminal proceedings by courts on the basis of agreements] (Plenum VSSU) [Plenum of the Supreme Specialized Court of Ukraine for Civil and Criminal Cases]. Ofitsiinyi sait Verkhovnoi Rady Ukrainy [Official site of the Verkhovna Rada of Ukraine]. <https://zakon.rada.gov.ua/laws/show/v0013740-15\#Text>. [in Ukrainian].

10. Tverdokhlib, M.H. (2016). Problemy zakonodavchoho vdoskonalennia kryminalnoho provadzhennia na pidstavi uhod [Problems of legislative improvement of criminal proceedings on the basis of agreements]. Porivnialno analitychne pravo [Comparative analytical law], no. 1. [in Ukrainian].

11. Uzahalnennia VSSU sudovoi praktyky zdiisnennia kryminalnoho provadzhennia na pidstavi uhod vid 22.01.2014 [Generalization of the Supreme Court of Ukraine judicial practice of criminal proceedings on the basis of agreements dated 22.01.2014]. Zakon i Biznes [Law and Business]. <https://zib.com.ua/ua/print/92557uzagalnennya_vssu_sudovoi_praktiki_zdiysnennya_kriminalnogo.htm $>$. [in Ukrainian].

12. Ukhvala Kamianko-Buzkoho raionnoho sudu Lvivskoi oblasti vid 08.02.2017 za №446/2168/16-k [Decision of the Kamyanka-Buzka District Court of the Lviv Region of February 8, 2017 under za446 / 2168/16-k]. $<$ http://www.reyestr.court.gov.ua/Review/64603727>. [in Ukrainian].

13. Ukhvala u provadzhenni № 1-kp/459/150/2017 2017 [Resolution in the proceedings № 1-kp / 459/150/2017 2017] (Chervonohradskyi miskyi sud Lvivskoi oblasti) [(Chervonohrad City Court of Lviv Region)].

$<$ http://www.reyestr.court.gov.ua/Review/66097457>. [in Ukrainian].

14. Ukhvala Chervonohradskoho miskoho sudu Lvivskoi oblasti 2016 za № 459/1934/16-k [Decision of the Chervonohrad City Court of the Lviv Region 2016 for № 459/1934/16-k]. <http://www.reyestr.court.gov.ua/Review/59237276>. [in Ukrainian].

15. Khavroniuk, M.I. (2017). «Pravoprokurorria», abo Deiaki problemy uhody pro vyznannia vynuvatosti ["Attorney General", or Some problems of plea agreement]. <http://pgp-journal.kiev.ua/archive/2017/4/34.pdf>. [in Ukrainian]. 